Безлюдна Валентина кандидат педагогічних наук, доцент, професор кафедри вікової та педагогічної психології http://orcid.org/0000-0003-3276-3427

Павелків Віталій

доктор психологічних наук, професор, декан психолого-природничого факультету Рівненського державного гуманітарного університету http://orcid.org/0000-0003-3321-9060

Осьмак Любов кандидат психологічних наук, доцент кафедри вікової та педагогічної психології Рівненського державного гуманітарного університету http://orcid.org/0000-0001-8188-7106 DOI https://doi.org/10.35619/prap_rv.vi14.147

\title{
ПСИХОЛОГІЧНІ ОСОБЛИВОСТІ СОЦІАЛЬНО-ПЕРЦЕПТИВНИХ ОЦІНОК В СИСТЕМІ «СТАРШОКЛАСНИК-ВЧИТЕЛЬ»
}

Анотація. Стаття присвячена висвітленню однієї із центральних умов успішності навчання $і$ навчальної діяльності підлітків - налагодженню продуктивних взаємозв'язків із учителем. Основою цього процесу є співпадіння системи уявлень про партнера по взаємодї у кожного із учасників навчально-виховного прочесу. Об'єктивність сочіально-перцептивного сприйняття, відсутність упереджень та стереотипових приписів забезпечують побудову продуктивних стосунків між вчителем і учнем. В емпіричному дослідженні брали участь 49 старшокласників та 10 вчителів. Перевірялася узгодженість соціально-периептивних оцінок за основними особистісними якостями підлітків, щъо беруть участь у побудові стосунків. Встановлено, що за показником визнання периептивно-інтерактивної компетентності простежується не лише низький рівень сформованості якості, а й наявність розбіжності у ї̈ взаємо- та самооцінуванні. Серед иести характеристик комунікативно-периептивної компетентності найнижчі показники отримані за шкалою соиіальної адаптованості. Високі оцінки отримані за показником стійкість емоційних станів учнів та їх взаємоузгодженість у позиціях обох учасників навчального прочесу.

Питання стереотипізаиії сприйняття та упереджень простежено в дослідженні иляхом аналізу образу ідеального учня. На основі співставлення уявлень представників двох вибірок щодо шести інструментальних типів успішного учня встановлено наявність суттєвих відмінностей у системі соціально-перцептивних установок: педагоги зорієнтовані на визнання схильності учня до творчого підходу у навчанні, учні - на виокремлення мотиваційно-трудової складової навчальної діяльності. За результатами проведеного дослідження встановлено, щзо взаємо- $i$ самоочінювання сочіально-значущих якостей старшокласників в иілому взаємоузгоджені, хоча їх рівневі показники вказують на наявність вищої критичності у підлітковому сприйманні

Ключові слова: перцептивно-інтерактивна компетентність, упередження, оцінки, взаємооиінки, соиіально-периееттивне сприйняття, старшокласники, якості особистості

Постановка проблеми. Вивчення особливостей сприймання людини-людиною здійснюється в психології уже досить давно (Брунер, Бодальов, Кентріл). Та незважаючи на це, проблема не втратила своєї актуальності і гостроти. Особливу значущість вона має у діадичній взаємодії «вчитель-учень». Сприймання вчителями учнів $є$ дуже важливим питанням як для самих педагогів, так і для учнів та їхніх батьків. Відомо, що успішність школярів багато у чому залежить від характеру соціально-перцептивного оцінювання з боку вчителя, яке виникає у процесі 
узагальнення ним свого досвіду спілкування з учнями. Неадекватне сприйняття учня вчителем породжує формування дисгармонійних, непродуктивних зв'язків між ними i, як наслідок, негативно позначається на успішності навчальної діяльності та розвитку особистості підлітка. Варто зазначити, що проблема стереотипізації, навішування «ярликів», досить часто зустрічається в наших школах, породжуючи виникнення конфліктів між учасниками навчально-виховного процесу. Наслідками неадекватного взаємосприймання може бути втрата інтересу дітей до навчання, зниження академічної успішності, порушення емоційної рівноваги та багато інших не менш серйозних розладів. Саме тому потрібно якомога детальніше вивчати цю проблему та здійснювати розробку спеціальних профілактичних заходів запобігання виникненню неадекватних соціально-перцептивних оцінок як зі сторони вчителів, так і їх вихованців.

Аналіз останніх досліджень i публікацій. Питання стосунків i особистісних взаємооцінювань між учасниками освітнього процесу має уже давні історичні традиції. Вони піднімалися у робох українських психологів (Ніколенко (1988); Власенко,1995, Раздобулько, 1975) ; білоруських (Коломінський, 1999; Реан, 2009), російських (Сршова,1997 Максакова,1975). На сьогодні виконані аналітичні огляди по узагальненню проблеми (Фоміченко, 2012; Періус 2016), а також здійснюється подальша іiі розробка (Велитченко, 2006; Завгородня, Лукомська, Копилов, Котух, 2019). У психологічних роботах аналізуються питання розвитку комунікативних компетенцій вчителя, особливості та наслідки використання ним різних стилів комунікативної взаємодії. Все ж питання узгодженості процесів соціального сприйняття, співпадіння системи уявлень про партнера по взаємодії у кожного із учасників навчально-виховного процесу залишається на часі.

Мета статті полягає у висвітленні особливостей соціально-перцептивних оцінок в дідичній системі «старшокласник-вчитель», простеженні відмінностей між самосприйняттям старшокласників та оцінюванням їх особистісних якостей вчителями.

Виклад основного матеріалу дослідження. В ході емпіричної розробки проблеми нами були використано наступні методики: опитувальник «Діагностика перцептивно-інтерактивної компетентності» (модиф. Фетіскіна); «Діагностика перцептивно-образної самооцінки» (авт. Бойко), «Методика дослідження стереотипів сприймання успішного учня»; «Методика інтерперсональної взаємодії» (Т. Лірі). Дослідження проводилося на базі Рівненської української гімназії. В дослідженні брали участь 49 старшокласників віком від 16 до 17 років (з них 27 осіб чоловічої статі та 22 - жіночої) та 10 вчителів (4 особи чоловічої статі та 6 жіночої статі).

Наукове спостереження розпочиналося із вивчення особистісної готовності учнів до формування інтегративних критеріїв інтерактивної компетенції в межах своєї групи, а також оцінювання рівня сформованості цієї учнівської здатності їхніми вчителями. Як видно із таблиці 1., серед шести діагностованих характеристик комунікативно-перцептивної компетентності найнижчі показники в оціночних судженнях школярів отримали параметри шкали соціальної адаптованості (середній бал 15 із 20 можливих).

Таблиця 1.

Показники самооцінювання та оцінювання перцептивно-інтерактивної компетентності стариокласників

\begin{tabular}{|l|c|c|c|c|c|c|c|}
\hline \multirow{2}{*}{ Категорія оцінок } & \multicolumn{6}{|c|}{ Показники характеристик перцептивно-інтерактивної компетентності } \\
\cline { 2 - 8 } & 1 & 2 & 3 & 4 & 5 & 6 & $\begin{array}{c}\text { Загальний } \\
\text { показник }\end{array}$ \\
\hline $\begin{array}{l}\text { самооцінки } \\
\text { старшокласників }\end{array}$ & 20 & 20 & 18 & 25 & 15 & 18 & 116 \\
\hline оцінки вчителів & 18 & 18 & 15 & 22 & 17 & 17 & 106 \\
\hline
\end{tabular}

1. взаємопізнання; 2. взаєморозуміння; 3. взаємовплив; 4. соціальна автономність; 5. соціальна адаптованість; 6. соціальна активність. 
Це може свідчити про усвідомлення підлітками наявності певних несприятливих тенденцій у власних статусних позиціях, переживанні дискомфорту при оцінюванні свого положення в групі та в цілому, у сприйнятті стосунків у своїй спільноті. При декларуванні підлітками таких оціночних суджень можна також говорити про недостатній рівень сформованості гнучкості поведінки та їх контактності з однолітками як у системі звичної для них спільноти, так і з більш широким зовнішнім оточенням. Натомість, більш високий рівень визнання отримали змінні взаємопізнання (сер. бал 20); взаєморозуміння (сер. бал 20) та соціальної автономії (сер. бал 25). Задекларовані позиції вказують на те, що підлітки відчувають у собі здатність адекватно оцінювати особистісні якості партнерів по взаємодії, вони декларують низький рівень конфліктності в групі. Старшокласники визнають наявність орієнтацій на пошук спільних інтересів, здатність зрозуміти точку зору партнера. Із відповідей випливає, що старшокласники розуміють значимість особистісної позиції в спільних діях і облаштуванні спільної діяльності. Це може свідчити про сформованість когнітивно-мотиваційних основ спілкування та належну згуртованість групи. Все ж, загальний показник (116 балів), вказує на низький рівень комунікативної інтерактивності у наших респондентів. Аналіз рівневої диференціації вибірки засвідчує, що у жодного із учасників обстеження не було виявлено високого рівня сформованості цієї якості. Натомість більшість обстежених продемонстрували низький рівень означених схильностей (див. рис.1.).

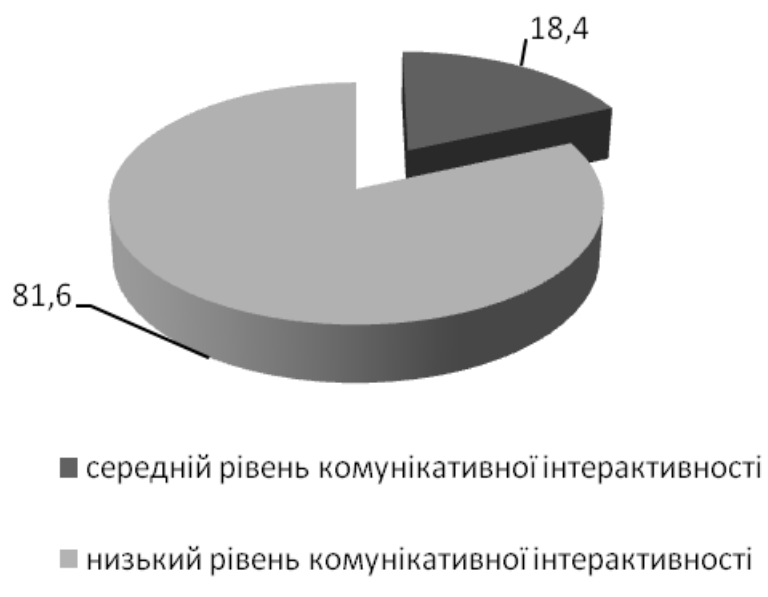

\section{Рис. 1. Показники розподілу вибірки за критерісм рівня сформованості комунікативної інтерактивності}

За нашим розумінням, однією із причин низьких рівнів комунікативної інтерактивності може слугувати розлагодженість у системі стосунків «вчитель-учень». Депривування позитивних якостей підлітків у процесі педагогічного оцінювання може спровокувати погіршення психологічної атмосфери самосприйняття підлітками своїх компетенцій. Для перевірки гіпотези було виконано аналіз оціночних суджень вчителів, щодо особистісних якостей учнів та їх соціальних компетенцій. Як засвідчують результати опитування, найменш сформованою інтерактивною схильністю учнів, на думку дорослих, є здатність до взаємовпливу. Вчителі вважають, що підлітки не надають належного значення позиціям та вчинкам інших представників групи, не враховують їх при побудові стосунків та власних поведінкових програм. Вони не завжди здатні до самокорекції власної поведінки та саморефлексії.

Отже, вчителі вважають, що старшокласники не завжди в змозі корегувати та оцінити свою поведінку в певній ситуації. Закономірно, що через неспівпадіння оціночних установок за цим критерієм між учнями та вчителями можуть виникати проблемні ситуації, що напружує взаємодію 
та впливає на процес і результатах навчальної діяльності школярів. Все ж варто визнати, що за деякими критеріями оціночні судження учнів і вчителів співпадають. Зокрема таке узгодження, простежується за показником «соціальна адаптованість». Зазначимо, що дану схильність вчителі оцінили вище, ніж самі старшокласники. Величина середнього балу відповідно 17 і 15 (див. табл. 1.). Загальний показник комунікативної інтерактивності в оціночних позиціях і дорослих, i старшокласників знаходиться на рівні низьких значень (відповідно 106 і 106 балів). На основі отриманих даних, ми можемо припустити, що між оцінками старшокласників та вчителів є суттєва відмінність. Враховуючи кількісну нетотожність задіяних вибірок, для підтвердження припущення був використаний $\mathrm{t}$-критерій Стьюдента. Його величина $(\mathrm{t}=2,2)$ при заданій вірогідності допустимої помилки 0,05, вказує на те, що середні значення по означених вибірках статистично різняться. Таким чином наше припущення знайшло своє підтвердження.

Оскільки сприйняття себе і партнерів значною мірою залежить від стійкості емоційної складової «Я-образу» ми спробували простежити цю закономірність за допомогою методики перцептивно-образної самооцінки Бойка. Як видно із таблиці 2 і учні і їхні вчителі оцінюють стійкість власних емоційних станів досить високо. Середні показники відповідно - 7,3 та 7,7 бали (див. табл. 2). Критерій Стьюдента $(\mathrm{t}=2,03)$ засвідчує відсутність статистично значущих відмінностей між показниками. На основі цих даних можна припустити, що вчителі адекватно оцінюють емоційні стани вихованців.

Таблиия 2.

Показники оцінювання і самооцінювання стійкості емоційних станів стариокласників

$N=49$

\begin{tabular}{|c|c|}
\hline Категорія оцінок & Показники стійкості емоційних станів \\
\hline самооцінки старшокласників & 7,7 \\
\hline оцінки вчителів & 7,3 \\
\hline
\end{tabular}

Однією із складних проблем школи є необхідність контролю за наявністю стереотипізації у сприйманні учасниками навчально-виховного процесу один-одного та потреба нівелювання дії упереджень у системі навчальної взаємодії. У нашому дослідженні питання стереотипізації сприйняття простежувалося шляхом аналізу уявлень старшокласників і вчителів щодо образу ідеального учня. В результаті їх аналізу ми отримали інформацію про існування певних стереотипів оцінювання образу учня та його учбової діяльності. Згідно використаного інструментарію, ми співставили уявлення представників двох вибірок щодо шести інструментальних типів успішного учня: суб’єктивно-творчого, загальнотрудового, мотиваційновольового, пристосувального, типу із сформованими учбовими уміннями та типу із розвиненими пізнавальними здібностями. Як видно із таблиці 3, у позиціях старшокласників на першому місці позначено мотиваційно-вольовий тип та тип володіння пізнавальними здібностями (відповідно 18,35 і 18,14 бали). Отже, на думку учнів, головну роль у досягненні успіху у навчанні відіграють вольові якості та наявність вроджених розумових здібностей (див. табл. 3).

Таблиия 3.

Інструментальні типи успішного учня на думку стариокласників та вчителів

\begin{tabular}{|l|c|c|c|c|c|c|}
\hline \multirow{2}{*}{ Категорія оцінок } & \multicolumn{6}{|c|}{ Показники інструментальних типів успішного учня } \\
\cline { 2 - 7 } & $\mathrm{CT}$ & $3 \mathrm{~T}$ & УВ & П3 & МВ & П \\
\hline $\begin{array}{l}\text { самооцінки } \\
\text { старшокласників }\end{array}$ & 18,02 & 15,84 & 17,65 & 18,14 & 18,35 & 14,9 \\
\hline оцінки вчителів & 18,1 & 17,1 & 18,3 & 17,6 & 17,9 & 12,4 \\
\hline
\end{tabular}

СТ - суб'єктивно-творчий; ЗТ - загальнотрудовий; УВ - володіє учбовими вміннями; ПЗ - володіє гарними пізнавальними здібностями; МВ - мотиваційно-вольовий; П - пристосовницький

Останні позиції зайняли загальнотрудовий та пристосовницький типи $(15,84$ і 14,94 балів відповідно). Старшокласники вважають, що такі якості як дисциплінованість, працьовитість, 
відповідальність, акуратність, слухняність менш значущі для успішного навчання, ніж раніше означені.

У позиціях вчителів перші рангові місця отримав суб'єктивно-творчий тип та тип володіння учбовими вміннями $(18,1$ і 18,3). Як бачимо, увага педагогів більше зорієнтована на наявність в учня творчого ставлення до навчання у поєднанні з оволодінням основними учбовими вміннями, такими як: вміння самостійно ставити перед собою цілі в учбовій діяльності, вміння планувати свою роботу і виконувати цей план, володіння самоконтролем та вміння працювати 3 підручником. На останні місця вчителі, як i учні, поставили загальнотрудовий та пристосовницький типи (17,1 i 12,4 бали). Виявлені стереотипи дозволяють з'ясувати індивідуальні уявлення вчителів та старшокласників про сутність навчальної діяльності учня та виявити розбіжності і співпадіння у цих поглядах. Зокрема, простежується співпадання в найменш важливих (як на думку вчителів, так і старшокласників) типах успішного учня. У той час як за рейтингом найбільш значущих типів простежується розбіжність. (Показник критерію Стьюдента $\mathrm{t}$ $=2,3$ засвідчує, що середні значення по вибірках статистично достовірно відрізняються). Закономірно, що наявність тенденції до неспівпадіння позицій може провокувати виникнення проблем при викладанні певного матеріалу вчителем, чи при його засвоєнні учнями. Як наслідок, можуть виникати проблеми щодо втрати старшокласниками мотивації до навчання.

Навчальний процес, це складна взаємодія партнерів, що мають різні статусні позиції статус вчителя та статус учня. Успішність їх співпраці значною мірою залежить від особистісних установок і індивідуальних схильностей щодо спілкування і побудови стосунків 3 людьми. Для їх простеження у своєму дослідженні ми скористалися методикою аналізу уявлень людини про себе як суб' єкта соціальної взаємодії. У результаті опитування були виявлені домінуючі типи ставлень до інших через само- та взаємооцінювання. Як видно із таблиці 4, у самооціночних судженнях учнів високі бали $(8,6$ і 9,5) простежуються за підозріливим та залежним типами ставлень, тобто у них спостерігається екстремальна поведінка за цими типами (див. табл. 4).

Таблиияя 4.

\section{Співвідночення типів ставлень до себе та інших}

\begin{tabular}{|l|c|c|c|c|c|c|c|c|}
\hline \multirow{2}{*}{ Категорія оцінок } & \multicolumn{8}{|c|}{ Кількісні показники основних типи ставлень } \\
\cline { 2 - 9 } & 1 & 2 & 3 & 4 & 5 & 6 & 7 & 8 \\
\hline $\begin{array}{l}\text { самооцінки } \\
\text { старшокласників }\end{array}$ & 7,9 & 7,7 & 8,1 & 8,6 & 7,7 & 9,5 & 7,9 & 7,4 \\
\hline оцінки вчителів & 7,1 & 7,9 & 7,2 & 8,3 & 7 & 8,9 & 6,5 & 6,5 \\
\hline
\end{tabular}

1.авторитарний; 2. егоїстичний;-3.агресивний; 4.підозріливий; 5.схильний до підкорення; 6.залежний; 7. дружелюбний; 8.альтруїстичний.

Із цих результатів можна зробити висновок, що старшокласники оцінюють свою поведінку досить критично, визнають наявність труднощів у інтерперсональних контактах через невпевненість в собі, скептичність, прояв негативізму у вербальній агресії, іноді надмірній покірності та невмінні відстоювати свою думку. За результатами оцінювання вчителями можна сказати, що вони мають про своїх вихованців таку ж думку. Їхні показники майже збігаються 3 оціночними судженнями учнів хоча означені типи отримують дещо нижчі показники $(8,3$ і 8,9 бали відповідно). Можна робити висновок, що вчителі оцінюють поведінку старшокласників як більш адаптивну, тоді як самі учні схильні оцінювати їі як більш екстремальну. Усі інші показники знаходяться в межах норми, як за оцінками старшокласників, так і оціночними судженнями вчителів. Відмінність у оцінюванні старшокласниками і вчителями показників домінування та дружелюбності подано у таблиці 5. Виходячи із отриманих даних, ми можемо робити висновок про те, що домінування, як особистісна стратегія, отримала близьку міру визнання як у оціночних судженнях старшокласників, так і вчителів. Це означає, що старшокласникам, у процесі навчальної взаємодії, більш властиве підкорення, ніж домінування і вчителі адекватно оцінюють ці схильності (показники відповідно 2,7 і 2,1). 
Співвідночення показників домінування та дружелюбності у старшокласників на Табличя 5 основі оцінювання вчителями та самооцінювання

\begin{tabular}{|l|c|c|}
\hline \multirow{2}{*}{$\begin{array}{l}\text { Особистісні } \\
\text { схильності }\end{array}$} & \multicolumn{2}{|c|}{$\begin{array}{c}\text { Кількісні показники визнання особистісних схильностей } \\
\text { старшокласників }\end{array}$} \\
\cline { 2 - 3 } & $\begin{array}{l}\text { самооцінки } \\
\text { старшокласників }\end{array}$ & оцінки вчителів \\
\hline Домінування & $-2,1$ & $-2,1$ \\
\hline Дружелюбність & $-0,7$ & $-1,7$ \\
\hline
\end{tabular}

За критерієм дружелюбності ми спостерігаємо більший розкид позицій. Вчителі схильні більш критично ставитися до гуманістичних налаштувань своїх вихованців. У зіставленні із показниками самооцінювання педагоги оцінюють учнів як менш дружелюбних. Підсумовуючи зазначимо, що у вчителів та старшокласників простежується певна відмінність у сприйнятті особистісних якостей останніх (критерій Стьюдента $\mathrm{t}=2,2$ свідчить про статистичну достовірність відмінностей $\mathrm{p}<0,05)$.

3 метою зіставлення отриманих результатів подамо їх у формі зведеної таблиці. Вона забезпечує презентацію загальної картину соціально-перцептивних оцінок за всіма методиками

Зведена таблиця результатів

Табличя 6.

\begin{tabular}{|c|c|c|c|}
\hline \multirow[t]{2}{*}{ Методики } & \multirow[t]{2}{*}{ Характеристики } & \multicolumn{2}{|c|}{ Кількісні показники } \\
\hline & & $\begin{array}{l}\text { самооцінки } \\
\text { старшокласників }\end{array}$ & $\begin{array}{l}\text { оцінки } \\
\text { вчителів }\end{array}$ \\
\hline \multirow{6}{*}{$\begin{array}{l}\text { Діагностика перцептивно- } \\
\text { інтерактивної компетентності } \\
\text { (модиф. Фетіскіна) }\end{array}$} & взаємопізнання & 20 & 18 \\
\hline & взаєморозуміння & 20 & 18 \\
\hline & взаємовплив & 18 & 15 \\
\hline & соціальна автономія & 24 & 22 \\
\hline & соціальна адаптованість & 15 & 17 \\
\hline & соціальна активність & 18 & 17 \\
\hline $\begin{array}{l}\text { Діагностика перцептивно- } \\
\text { образної самооцінки» (Бойко) }\end{array}$ & стійкість емоційних станів & 7,26 & 7,74 \\
\hline \multirow{6}{*}{$\begin{array}{l}\text { Методика дослідження } \\
\text { стереотипів сприймання } \\
\text { успішного учня }\end{array}$} & суб’єктивно-творчий тип & 18,02 & 18,1 \\
\hline & загальнотрудовий тип & 15,84 & 17,1 \\
\hline & тип волод. учб. вміннями & 17,65 & 18,3 \\
\hline & тип волод. пізнав. здібн. & 18,14 & 17,6 \\
\hline & мотиваційно-вольовий тип & 18,35 & 17,9 \\
\hline & пристосовницький тип & 14,94 & 12,4 \\
\hline \multirow{8}{*}{$\begin{array}{l}\text { Методика інтерперсональної } \\
\text { взаємодії (Лірі) }\end{array}$} & авторитарний & 7,9 & 7,1 \\
\hline & егоїстичний & 7,7 & 7,9 \\
\hline & агресивний & 8,1 & 7,2 \\
\hline & підозріливий & 8,6 & 8,3 \\
\hline & схильний до підкорення & 7,7 & 7 \\
\hline & залежний & 9,5 & 8,9 \\
\hline & дружелюбний & 7,9 & 6,5 \\
\hline & альтруїстичний & 7,4 & 6,5 \\
\hline
\end{tabular}


Зіставляючи результати усіх методик, бачимо, що при самооцінюванні старшокласники практично за всіма показниками використали вищі бали ніж ті, якими їх оцінювали вчителі. Наявність певної невідповідності у самосприйнятті та оцінюванні з боку авторитетних дорослих вказує на необхідність здійснення коригування соціально-перцептивного сприйняття та оцінювання старшокласників. Розвивально-корегуючі впливи можуть посприяти не лише формуванню більш адекватного оцінювання, а й покращення стосунків в освітньому просторі школи.

Висновки. Виконані спостереження засвідчили наявність певних розбіжностей у системі самооцінювання учнів та сприйнятті їх образу вчителями. Наявність цих тенденцій може виступати підгрунтям формування упереджень у освітньому просторі школи. Це вказує на доцільність здійснення психологічної курації процесів соціально-перцептивного сприйняття, розвитку перцептивно-інтерактивної компетентності, що сприятиме побудові продуктивних стосунків між вчителем і учнем.

\section{СПИСОК ПОСИЛАНЬ}

Велитченко Л. К., 2006 Психологічні основи педагогічної взаємодї. (Дис. канд. психол. н.) Національний педагогічний університет імені М. П. Драгоманова, Київ.

Періус, Н. В. (2012) Особливості соціально-психологічної компетентності педагогів. Актуальні проблеми соичілогії, психології, педагогіки. 15, 161-168.

Психологія педагогічної взаємодї: інтегративний підхід: монографія (2019). В. Л. Зливков, О. В. Завгородня, С. О. Лукомська, С. О. Копилов, О. В. Котух; за ред. В. Л. Зливкова, С. О. Лукомської. - Київ.

Фетискин, Н.П., Козлов В.В., Мануйлов Г.М. (2002) Социально-психологическая диагностика развития личности и малых групп. - Москва. Изд-во Института Психотерапии.

Фомиченко, А. С. (2012) Психологические и гендерные особенности понимания учителем личности ученика. Вестник ЮУрГУ, 19. «Психология», 17

Червинская, К. Р. (2008) Методика интерперсональных отношений: опыт эксплииирования знаний эксперта-психолога, интерпретационные схемы. Методическое пособие. - СПб.: Речь.

\section{REFERENCES}

Velytchenko, L. K., 2006 Psykholohichni osnovy pedahohichnoi vzaiemodii. (Dys. kand. psykhol. n.) [Psychological basis of pedagogical interaction] Natsionalnyi pedahohichnyi universytet imeni M. P. Drahomanova, Kyiv. [in Ukrainian].

Perius, N. V. (2012) Osoblyvosti sotsialno-psykholohichnoi kompetentnosti pedahohiv. Aktualni problemy sotsiolohii, psykholohii, pedahohiky. 15, 161-168. [in Ukrainian].

Psykholohiia pedahohichnoi vzaiemodii: intehratyvnyi pidkhid: monohrafiia (2019). V.L. Zlyvkov, O.V. Zavhorodnia, S.O. Lukomska, S.O. Kopylov, O.V. Kotukh; za red. V. L. Zlyvkova, S.O. Lukomskoi. - Kyiv. [in Ukrainian].

Fetiskin, N.P., Kozlov V.V., Manujlov G.M. (2002) Soczial`no-psikhologicheskaya diagnostika razvitiya lichnosti i maly `kh grupp. - Moskva. Izd-vo Instituta Psikhoterapii. [In Russian].

Fomichenko, A. S. (2012) Psikhologicheskie i genderny`e osobennosti ponimaniya uchitelem lichnosti uchenika. Vestnik YuUrGU, 19. «Psikhologiya», 17 [In Russian].

Chervinskaya, K. R. (2008) Metodika interpersonal`ny`kh otnoshenij: opy`t e`kspliczirovaniya znanij e`ksperta-psikhologa, interpretaczionny`e skhemy`. Metodicheskoe posobie. - SPb.: Rech [In Russian]. 


\title{
PSYCHOLOGICAL FEATURES OF SOCIAL AND PERCEPTIVE ASSESSMENT IN THE SYSTEM OF «HIGH SCHOOL STUDENT - TEACHER»
}

\author{
Valentyna Bezliudna \\ Candidate of pedagogical sciences, professor, \\ Department of Developmental \& Educational Psychology \\ Rivne State University of the Humanities \\ http://orcid.org/0000-0003-3276-3427
}

Vitalij Pavelkiv

Doctor of psychological sciences, professor, Dean of Faculty of Psychology and Natural Science Rivne State University of the Humanities http://orcid.org/0000-0003-3321-9060

Liubov Osmak, Candidate of psychological sciences, associate professor, Department of Lifespan \& Pedagogical Psychology

Rivne State University of the Humanities http://orcid.org/0000-0001-8188-7106 DOI https://doi.org/10.35619/prap_rv.vi14.147

\begin{abstract}
The article is devoted to the discovery of one of the main conditions of juveniles' successful learning and educational activity that is establishing efficient relations with a teacher. The basis of this process is correspondence of the system of ideas about the interaction partner of every member of educational process. Social perception objectivity, lack of prejudice and stereotypes provide efficient relations between teacher and student. 49 high-schoolers and 10 teachers participated in empirical research. The coordination of social and perceptive assessments have been examined for the juveniles' basic personality traits involved in relations building. It is determined that the perceptive and interactive competence index shows both the law level of quality formation and its mutual and selfestimation divergence.

The lowest indices among six characteristics of communicative and perceptive competences have been got on the scale of social adaptability. High assessments have been got according to the index of emotional stability states of the students and their mutual consistency in positions of both participants of educational process.

The problem of stereotype perception and prejudice in the research is observed by means of analyzing the ideal student image. The comparison of ideas of two samples representatives of six instrumental types of successful student (subjective-creative, working, motivational and volitional, adaptive, with developed learning skills, with developed cognitive abilities) defined essential difference in the system of social and perceptive patterns: teaches are oriented on student's disposition to creative learning approach, students are oriented on motivational and working components distinguishing. The mismatch of positions is imbalance basis of educational interaction organization.

According to the results of the research it is defined that the mutual and self-assessment of socially significant qualities of high-schoolers are in general mutually consequent. Though their level indices indicate higher criticism in adolescent perception.

The conclusion can be done that the teachers assess high school students' behavior as more adoptive, high schoolers as extremer.
\end{abstract}

Key words: perceptive and interactive competence, prejudice, assessments, mutual assessments, social perception, high school students, personal qualities. 